\title{
ANALYSIS OF DEPRECIATION POLICY BASED ON EFFECTIVE TAX RATE
}

\author{
Krishna Kumar Shah \\ Department of Management, TU, Thakur Ram Multiple Campus, Birgunj, Nepal \\ Email: associateskkshah@gmail.com
}

\begin{abstract}
Depreciation is an income tax deduction that allows a tax payer to recover the cost. It is an annually allowance for the wear and tear, deterioration or obsolesce of property. With the introduction of income tax Act 2002 the government claimed that the depreciation rule under the new law is more generous than the depreciation rule in 1992 in case of all the assets including machinery and building. This article compares Effective Tax Rate (ETR) which shows no decrease in 2002 in compassion to 1992 in ETR. It means the depreciation rule of 2002 in case of building and machinery is not generous as claimed by the tax policy maker. In contrary to this, the analysis shows that the depreciation provision of 1992 and 2002 are more liberal than the depreciation provision of 1982.
\end{abstract}

\section{Key words}

Depreciation; ERT; depreciable; generous; policy; liberal

\section{Introduction}

Depreciation allows for the wear and tear on fixed assets and must be deducted from your income. Depreciation is claimed on fixed assets used in business that have a useful life span of more than one year. Not all fixed assets can be depreciated. It is a non-cash expense that reduces the value of assets as a result of wear and tear or obsolescence. Most assets lose their value over time, in other words, they depreciate, and must be replaced at the end of their useful life. There are several accounting methods that are used in order to write-off an asset's depreciation cost over the period of its useful life.

\section{Tax depreciation policy in Nepal}

In context of Nepal, tax depreciation policy has exercised various rates of depreciation system prescribed by various income tax related acts and rules. After the introduction of depreciation policy act in 1962, the method of depreciation proposed was straight line (Fixed Installment) and the rate allowed were 10 percent for plant and machinery, 6 percent for buildings, 5 percent for furniture 
and 15 percent for vehicles. It was changed in 1974, 1981, 1982, 1992 and 2002 gradually. The introduction of income tax act 2002 made the depreciation system more wide and liberal than the previous ones, especially for industrial sector. According to income tax act 2002 depreciable assets are classified into five groups: structure group, office-related furniture and equipment group, vehicle group, machinery-equipment group and intangible asset group. The depreciation rates for these groups are 5 percent for building, 25 percent for office related furniture and equipment, 20 percent for vehicles, 15 percent for machinery items \& total cost dividend by life are intangible assets.

The effective tax rate for individuals is the average rate at which their yearly new income is taxed. The effective tax rate for corporation is the average rate at which its pre-tax profit is taxed. The ETR is computed dividing total tax expenses by the firm's earnings before taxes. The ETR is the net rate a tax pay or if all forms of taxes included and divided by taxable income. This theory of ETR is related to the theory of cost of capital developed by Jorgenson (1963). This theory was introduced in 1980 on the debate over the economic recovery tax act, 1981. This concept is used as a means of comparing tax burden across different types of assets.

\section{Method}

This paper incorporates secondary data related to income tax acts of various years. The tax depreciation rates used in calculation are based on the Income Tax Act 1962, Industrial Enterprise Act 1981, Income Tax Rule 1982, Industrial Enterprise $\Lambda$ ct 1992 and Income Tax Act 2002.Computation of ETR heads various models and parameters like inflation rate, interest tax rate, depreciation rate, return on asset, return on equity, debt equity ratio, dividend tax rate, capital tax rate, investment credit on VAT and so forth. This paper analyses the ETR only for building and machinery.

\section{Results and discussion}

Depreciation expenses are an accounting practice that reduces the book values of certain assesses across their depreciable live. Depreciation expenses lowers reported net income, thus creating a tax savings. In context

Table 1: Parameters for analysis of ETR

\begin{tabular}{|l|l|l|l|l|l|l|l|}
\hline Year & Int. Rate \% & $\begin{array}{c}\text { Int.Tax } \\
\text { Rate\% }\end{array}$ & $\begin{array}{c}\text { Dividend } \\
\text { Tax Rate\% }\end{array}$ & $\begin{array}{l}\text { Corporate } \\
\text { Tax Rate\% }\end{array}$ & $\begin{array}{c}\text { Inflation } \\
\text { Rate \% }\end{array}$ & \multicolumn{2}{c|}{$\begin{array}{c}\text { Capital gain Tax } \\
\text { Rate\% }\end{array}$} \\
\hline 1962 & 15 & 0 & 0.7 & 25 & 9.06 & 0 \\
\hline 1981 & 13 & 5 & 0 & 55 & 13.447 & 0 \\
\hline 1982 & 14 & 5 & 0 & 50 & 10.381 & 0 \\
\hline 1992 & 17 & 5 & 0 & 25 & 21.061 & 0 \\
\hline 2002 & 12 & 5 & 20 & 2.896 & 10 \\
\hline
\end{tabular}


of Nepal, tax depreciation policy parameter building and machinery is given in Table 1.

Depreciation expenses are charged according to service life (Table 2). The economic depreciation rate developed by Hulten and Frank (1981) for building and machinery were 3.7 percent and 13.33 percent respectively.

Table 3: Present values as depreciation of building and machinery

\begin{tabular}{|l|l|l|l|}
\hline \multirow{2}{*}{ Year } & \multirow{2}{*}{ Assets } & \multicolumn{2}{|c|}{ Sources of finance } \\
\cline { 3 - 4 } & & $\begin{array}{l}\text { \% Debt } \\
\text { finance }\end{array}$ & \multicolumn{1}{c|}{$\begin{array}{c}\text { \% equity } \\
\text { Finance }\end{array}$} \\
\hline \multirow{2}{*}{1962} & Building & 44 & 30 \\
& Machinery & 58 & 44 \\
\hline 1981 & Building & 55 & 29 \\
& Machinery & 72 & 48 \\
\hline 1982 & Building & 30 & 12 \\
& Machinery & 73 & 46 \\
\hline 1992 & Building & 35 & 25 \\
& Machinery & 61 & 50 \\
\hline 2002 & Building & 42 & 31 \\
& Machinery & 67 & 57 \\
\hline
\end{tabular}

As per Table 3, it is known that the present value is higher under full debt finance in comparison to full equity finance in case of both the assets. While comparing the present value of depreciation of different years, it is seen that in case of building it is in1982 provision When it is 30 percent of cost under debt financing and 12p ercent of cost under equity finance The reason of being this is decrease in deprecation rate in 1982 provision income position to previous and subsequent years. In case of machinery, the present value of deprecation is lowest in 1962 system when it is 58 percent under debt financing and 44 percent under equity financing. The table shows the present value of deprecation in 2002 system is more than the same in 1992 and previous year's system. ETR is not the function of tax and economic deprecation rate only rather it is also affected by various elements like interest rate, inflection rate, rates of different types, taxes, capital structure.

\section{Conclusion}

It is claimed by the Government of Nepal that the Income Tax Act 2002 has made the deprecation provision more liberal in comparison to 1992 and previous Acts for both assets building and machinery. The present value analysis of both provisions based on ETR compares the present value of depreciation and tax saving through depreciation and ETR under different assumptions. It concludes that the depreciation provision of 2002 is not much liberal compared to 1992 for building and machinery. There is different between previous 1992 and provision 2002. This analysis is made on the basis of the actual variables of 1992 and 2002 including capital gain and current income (dividend) tax. It seems that the ETR is increased in 2002 in comparison to 1992 but ETR increased due to dividend tax and capital tax.

\section{Reference}

Center Bureau of Statics (2001) Census of manufacluring, Kathmandu: Author

Jorgenson, D.W. (1963). Capital theory and investment Behaviors, USA: Papers and proc.

Ministry of finance, (2001), Financial Act, Kathmandu: Author

Ministry of Law \& justice (1961) Income Tax Act. Kathmandu, Author

Ministry of law and justices, (1961), Income Tax Act, Kathmandu: Author

Ministry of law and justices, (1981) Industrial enterprises Act, Kathmandu: Author

Ministry of law and justices, (1981), Income Tax Act, Kathmandu: Author

Ministry of law and justices, (1982), Income Tax Act, Kathmandu: Author

Ministry of law and justices, (1992), Income Tax Act, Kathmandu: Author

Ministry of law and justices, (2002), Income Tax Act, Kathmandu: Author

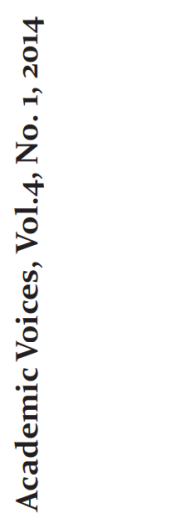

